\title{
Dermatological Practice in Nepal during COVID-19 Crisis: Recommendations of National Panel of Experts
}

\author{
Parajuli S 1 , Pokhrel DB ${ }^{1}$, Agrawal $\mathbf{S}^{2}$, Kumar $\mathbf{A}^{3}$, Pokhrel K ${ }^{4}$, Bastola $\mathbf{A}^{5}$, Bhattarai $\mathbf{S}^{6}$, Shrestha $\mathbf{S}^{7}$, \\ Shrestha $\mathbf{M}^{8}$, KC $\mathbf{S}^{9}$, Joshi $\mathbf{S}^{7}$, Das $A K^{1}$, Shah $\mathbf{M}^{10}$, Shah $\mathbf{N}^{2}$, Joshi SD ${ }^{11}$, Paudel $\mathbf{S}^{12}$, Hirachan $\mathbf{S}^{13}$, \\ Paudel $\mathbf{U}^{1}$, Neupane $\mathbf{S}^{14}$
}

${ }^{1}$ Tribhuvan University Teaching Hospital, Kathmandu, ${ }^{2}$ BP Koirala Institute of Health Sciences, Dharan, ${ }^{3}$ Manipal Teaching Hospital, Pokhara, ${ }^{4}$ Nepalgunj Medical College, Nepalgunj, ${ }^{5}$ Sukraraj Tropical and Infectious Disease Hospital, Kathmandu, ${ }^{6} \mathrm{Kathmandu}$ Medical College, Kathmandu, ${ }^{7} \mathrm{Nepal}$ Medical College, Kathmandu, ${ }^{8} \mathrm{KIST}$ Medical college, Lalitpur, ${ }^{9}$ Kathmandu University Hospital, Dhulikhel, ${ }^{10} \mathrm{DISHARC}$, Kathmandu, ${ }^{11}$ Seti Provincial Hospital, Dhangadhi, ${ }^{12}$ Civil Service Hospital, Kathmandu, Nepal, ${ }^{13}$ Bharatpur Hospital, Chitwan, ${ }^{14}$ Gandaki Medical College, Pokhara

\begin{abstract}
Introduction: Novel Coronavirus disease has caused a substantial halt to the ongoing world in every aspect. There are medical and social implications of the disease. Cutaneous manifestations have been reported to be a part of the disease as well. Dermatologists globally are in dilemma with the clinical practice because of the fear of acquiring the disease.

Objectives: This article aims to recommend best practice measures that can be followed in local scenario for re-opening of dermatological services in the context of Nepal.

Materials and Methods: A preliminary draft for guidance on Dermatological services based on recommendations of American Academy of Dermatology, International league of Dermatological societies, National recommendations from Ministry of Health, Nepal was sent to a panel of national experts to determine the level of consensus in first week of April, 2020. A preliminary survey was sent to all the members of Society of Dermatologists, Venereologists, and leprologists of Nepal on first week of June and a second draft was subsequently formed which was sent again to experts and revised based on the opinions of national experts.

Results: A total of 19 experts participated in the preparation of draft and reached a national consensus after a series of revisions in preliminary draft.

Conclusion: Agreements regarding the opening of practice in dermatology discipline have been summarized. Recommendations have been made for opening of dermatological services - opening of outpatient department, performing dermatosurgical and cosmetic procedures as well as strategies on triage of patients and use of masks.

Key words: Coronavirus; Dermatology; Disease; Nepal; Novel
\end{abstract}

\section{Introduction}

W have lately seen this passionate world motionless for months as if the nature has pressed a reset button. The World Health Organization (WHO) on December 31, 2019 received reports of patients with atypical pneumonia from Wuhan, Hubei Province, China caused by a new virus; Severe Acute

Financial disclosure: None.

Conflict of interest to disclosure: None declared.

Address of Correspondence

Dr. Upama Paudel

Associate Professor

Department of Dermatology and Venereology

Maharajgunj Medical Campus

Institute of Medicine, Tribhuvan University, Kathmandu, Nepal

E-mail: upama_ups@yahoo.com
Respiratory Syndrome Coronavirus 2 (SARS-CoV-2); currently designated as Coronavirus disease (COVID19). ${ }^{1}$ The infection promptly spread all over the world

Submitted: $1^{\text {st }}$ June 2020

Accepted: $3^{\text {rd }}$ July 2020

Published: $7^{\text {th }}$ October 2020

How to cite this article

Parajuli S, Pokhrel DB, Agrawal S, Kumar A, Pokhrel K, Bastola A, et al. Dermatological practice in Nepal during COVID-19 crisis: Recommendations of national panel of experts. Nepal Journal of Dermatology Venereology and Leprology 2020;18(1):3-8. https://dx.doi. org/10.3126/njdvl.v18i1.30378.



Licensed under CC BY 4.0 International License which permits use, distribution and reproduction in any medium, provided the original work is properly cited. 
escalating the condition and WHO eventually declared COVID-19 as a global pandemic on March 11, 2020. ${ }^{2}$ The data regarding the new cases detection and death rate is increasing day by day. Also, we should believe that such data could only be the "tip of an iceberg". Social life of people throughout the world has been disrupted with thousands of people losing their job. In Nepal, the first case of Corona virus was detected on 23rd January, 2020. ${ }^{3}$ Since then, cases have been increasing and the government has requested stayat- home order in Nepal since $24^{\text {th }}$ March, 2020. ${ }^{4}$ As the modalities of lockdown order have been changed by the government, the clinical practice has started opening up. In view of high transmission rates of SARSCoV-2 virus, reopening dermatological services remains a challenge. This article reviews available literatures on SARS-CoV-2 and has developed recommendations for opening up Dermatological services in our set up.

\section{Materials and Methods}

A first draft for guidance on Dermatological services based on recommendations of American Academy of Dermatology, International league of Dermatological societies, National recommendations from Ministry of Health, Nepal was delivered via email to panel of 19 national experts to determine the level of consensus in first week of April, 2020. At the same time the Government of Nepal first issued "Stay -at -home order". ${ }^{3}$ These 19 national experts were selected based on representation and expertise from different (Eastern part of Nepal to Western region of Nepal) parts of countries. This draft was circulated to all the members of Society of Dermatologists, Venereologists and Leprologists of Nepal. A second survey was sent to all the members of Society of Dermatologists, Venereologists, and Leprologists of Nepal on first week of June for feedback on first draft. A second draft was subsequently formed based on this feedback and sent again to panel of 19 experts via e-mail. The final draft and recommendations was formulated based on the opinions of majority of national experts. The survey was done using online google form and Microsoft excel was used to record the surveyed data.

\section{Recommendations}

\section{Virology}

Coronaviruses belong to the subfamily Orthocoronavirinae in the family Coronaviridae, Order Nidovirales. ${ }^{5}$ The genome of the virus is an enveloped, positive-sense, single-stranded RNA with fluctuating size between $26 \mathrm{~kb}$ and $32 \mathrm{~kb}$, the largest genome of known RNA viruses. Two latest outbreaks in this decade of viral pneumonia caused by $\beta$-CoVs are severe acute respiratory syndrome (SARS) and Middle East respiratory syndrome (MERS). ${ }^{5}$

\section{Modes of transmission}

Till date, it has become a well-known fact that this viral disease can be transmitted by droplets primarily, although surface contact transmissions from objects have also been reported. ${ }^{6}$ The average incubation period of SARS-CoV-2 is projected to be around 3-7 days (range, 2-14 days) representing a long transmission period of the virus. ${ }^{5,6}$

\section{Vaccines against SARS-CoV-2}

The development of vaccines against SARS-CoV-2 has been a priority worldwide to prevent Covid-19. Jackson et al ${ }^{7}$ reported preliminary report from phase1 trial evaluating safety and efficacy of mRNA SARSCoV-2 vaccine and the results have been promising. The dosing regimen of this vaccine is still under study and the authors indicate that planned phase 3 trial of this vaccine is imminent. ${ }^{7}$

\section{A. Recommendations for Outpatient Department (OPD) /Clinical practice 8-10}

1. In order to avoid crowd in outpatient department, encourage consultations through whattsapp/ viber hotline number for time being till the epidemic shows down trend. Reduce the number of new patients as per availability of consultants. Attend follow- up patients based on the urgency and need of the patients.

2. Encourage patients for online appointments.

3. It is advisable that health care workers should wear scrubs inside hospital premises/clinics. If they have to move out of OPD/place of practice, they can wear apron/white coat.

4. It is advisable to have following protective measures for health care worker for outpatient department (Attendants/Nurses/ Dermatologists)

a. Maintain Physical distance (2 m).

b. Wash hands with soap and water/Hand rub- alcohol based solution: before and after touching patients, documents and surroundings.

c. Use surgical mask and face shield throughout the OPD hours

5. Advise patients about hand hygiene and cough etiquette. Advise them to avoid unnecessary handling of stuff and surfaces while in the 
hospital or clinic. Document pictures of infection prevention in waiting areas of outpatient department. Disinfect all the areas on regular basis and document it.

6. Ensure the distance of two metres between patients and minimize the patients in waiting area by prior appointments.

7. Following questionnaires (see below) should be used by attendants of the hospitals/clinics for triage of Covid-19 suspected patients.

a. Do you have symptoms of cold? (Cough, runny nose): yes/no

b. Do you have currently an elevated body temperature/fever?: yes/no

c. In the past one month, have you been in hotspot areas considered to be at high risk for covid-19 disease? Yes/no

d. Have you been in contact with people suspected of COVID-19 within past 14 days? Yes/no

If there is answer yes to any of the above question, refer them to fever clinic of nearby COVID designated hospital for further evaluation and attend them after clearance from those clinics.

8. Patients' consultation:

a. Designate specific well ventilated rooms for consultation of patients depending upon the availability of rooms in hospital/clinic. Avoid air condition as far as possible.

b. Provide alcohol based hand sanitizer and disinfection solution in every consulting room and at the reception; ask patients to sanitize prior to entry and exit from the consulting room.

c. Wipe the door handles with alcohol based wipes after each consultation. To prevent occupational skin diseases after repeated hand washing, use barrier cream or emollient after hand sanitization.

d. Ask relatives, carers and parents of patients to be seated at designated seating in outpatient area or ask them to wait outside if not possible.

B. Recommendations for dermatosurgery and cosmetic procedures ${ }^{8,11-14}$

1. Avoid all non -essential, non-emergency dermatosurgical procedures. It has been seen that post- operative pulmonary complication, mortality is disproportionately high in SARS COV2 infected patients.

2. Follow all the steps 1 to 7 of recommendations on A before calling patients for the procedures.

3. If procedure is deemed appropriate triage the patient, send for reverse transcriptase polymerase chain reaction (RT-PCR) for SARSCoV-2 if necessary.

4. Limit waiting time before procedures by providing pre-procedure instructions through telecommunication e.g. to trim/shave the area for laser hair reduction, apply topical anesthesia one hour before procedure which can be done easily at home if given proper instructions.

5. Allow maximum of one to two patients in the waiting area of procedure room with strict social distancing; air-conditioning should be avoided in waiting areas with proper cross-ventilation and exhaust fan.

6. Ask the patients to sign a coronavirus selfdeclaration form stating their travel history, any symptoms of fever/cold/cough or shortness of breath

7. The consent form for procedure should include a statement regarding disinfection measures being taken during Covid-19 and should be duly signed by the patient before initiating any procedure.

8. General aesthetic procedures which can be carried out in Nepal during this pandemic can be divided in three categories and are summarized in Table 1.

Table 1: Procedures in Dermatology

\begin{tabular}{|c|c|c|}
\hline Non-invasive & Minimal invasive & Invasive \\
\hline $\begin{array}{l}\text { Superficial } \\
\text { chemical } \\
\text { peeling }\end{array}$ & Botulinum toxins & $\begin{array}{c}\text { Platelets rich } \\
\text { plasma }\end{array}$ \\
\hline $\begin{array}{c}\text { Intense pulsed } \\
\text { light }\end{array}$ & Filler injection & Fat grafting \\
\hline $\begin{array}{c}\text { Non-ablative } \\
\text { lasers }\end{array}$ & Microneedling & $\begin{array}{c}\text { Deep chemical } \\
\text { peeling }\end{array}$ \\
\hline \multirow[t]{4}{*}{$\begin{array}{l}\text { Radiofrequency } \\
\text { skin tightening }\end{array}$} & Microblading & Ablative lasers \\
\hline & Thread lift & $\begin{array}{c}\text { Mechanical } \\
\text { derma abrasion }\end{array}$ \\
\hline & Microdermabrasion & $\begin{array}{c}\text { Hair } \\
\text { transplantation }\end{array}$ \\
\hline & & Vitiligo Surgery \\
\hline
\end{tabular}

9. If you are planning to do procedures, minimal level of protection required will be as depicted in Table 2. 
Table 2: Types of procedures and level of protection

\begin{tabular}{|c|l|}
\hline Procedures & \multicolumn{1}{|c|}{ Minimal level of protection } \\
\hline Non-invasive & $\mathrm{N}-95$ mask/ Gloves \\
\hline Minimal Invasive & $\begin{array}{l}\mathrm{N}-95 \text { mask/ coverall/gloves/eye } \\
\text { shield }\end{array}$ \\
\hline \multirow{5}{*}{ Invasive } & $\begin{array}{l}\text { Personal respiratory protection: } \\
\text { N-95 mask/eye shield /gloves/ } \\
\text { ventilation protection with } \\
\text { some evacuator ( HEPA/UPLA) } \\
\text { HEPA: High efficiency } \\
\text { particulate air } \\
\text { UPLA: Ultra low particulate air }\end{array}$ \\
\hline
\end{tabular}

10. Performing laser procedures

i. Make patient wear the gown and expose only the area to be treated.

ii. Cover the body of the machine with disposable sheet/cling film for each procedure with the exhaust fan area open.

iii. Discard the sheet after each procedure.

iv. Clean the body of the machine, machine tubes, articulated arm with sodium hypochlorite $1 \%$ or $70 \%$ ethyl alcohol.

v. Touch screen, lens optics, cooling tip can be cleansed using $70 \%$ ethyl alcohol.

vi. Use disposable spatulas. In case spatulas are to be reused, clean with $70 \%$ ethyl alcohol.

vii. Eye Shields- Clean eye shields with $70 \%$ ethyl alcohol along with the strap.

viii. Laser gel - Take out gel in disposable cups for each procedure and discard after each procedure.

ix. Tattoo removal-Postpone if not urgent.

x. Use low power settings where possible to reduce the production of plumes.

xi. Ablative lasers, Q-switched laser, Laser hair removal generates more plumes as compared to non-ablative lasers or Light emitting diodes - perform with proper precautions including personal protective equipments (PPEs), adequate ventilation and smoke evacuation.

11. Using Injectable (Botulinum toxin /fillers)

i. Double pair of gloves should be worn.

ii. Area to be injected should be cleansed thoroughly.

iii. Disposal of syringes and needles using a needle destroyer should be done immediately post-procedure. iv. Suitable dressing to be used to seal injection points.

12. Use of $\mathrm{N}-95$ masks

i. Extended use - N-95 mask use can be safely extended for up to 8 hours (including between patients). Wearing a face-shield over the $\mathrm{N}-95$ mask decreases the chances of soiling of mask.

ii. Re-use - CDC recommends that assuming there is no soiling and minimal to no viral contamination the $\mathrm{N}-95$ mask can be reused for up to 5 times with use of following strategies:

- Acquire a set of at-least five N-95 masks and rotate their use each day assuring that there is no soiling of mask and minimal to no contamination with virus. Masks should be allowed to dry for a time period longer than the viability of the virus i.e. 72 hours. Each mask should be stored in a clean breathable paper bags separately without coming in contact with each other.

- Methods approved by CDC for reprocessing/ decontamination includes use of steam or liquid hydrogen peroxide. Moist heat at a temperature of $60-70^{\circ} \mathrm{C}$ and $80-85 \%$ relative humidity or dry heat at $70^{\circ} \mathrm{C}$ for 30 minutes has been shown to adequately kill the virus while preserving the filter integrity and fit.

- Use of alcohol, sanitizers, baking, microwave, boiling, ethylene oxide or soapy water are not approved by CDC and should be avoided as they compromise the electrostatic charge present inside the $\mathrm{N}-95$ mask.

13. General recommendations for Dermatosurgical procedures

i. Follow all the steps of 1 to 7 of recommendations $A$, before calling the patients for any surgical procedures.

ii. A triage of patients requiring surgical intervention has been recommended. All elective procedures (defined as skin lesions which are not of imminent danger to patients if not treated within 3-months) are postponed to later date depending on regular evaluation of skin lesions. On the basis of clinical judgement, various levels of urgency need to be assigned to patient needs.

Surgical patients should be limited to those requiring urgent biopsy, suspected 
malignancies, or acute or unbearable symptoms needing urgent care. The procedures are listed in Table 3.

Table 3: List of Procedures needing urgent care

\begin{tabular}{|l|l|}
\hline $\begin{array}{l}\text { Skin biopsies (Suspected } \\
\text { malignancies/ Bullous } \\
\text { disorders/ Vasculitis/ } \\
\text { Selected cases of } \\
\text { erythroderma) }\end{array}$ & $\begin{array}{l}\text { Excision of tumours } \\
\text { (atypical naevi/ Glomous } \\
\text { tumour/ Painful tumours }\end{array}$ \\
\hline $\begin{array}{l}\text { Incision and drainage of } \\
\text { cysts and abscesses }\end{array}$ & $\begin{array}{l}\text { Bleeding pyogenic } \\
\text { granulomas }\end{array}$ \\
\hline $\begin{array}{l}\text { Procedures for } \\
\text { immediate pain relief } \\
\text { (for example: painful } \\
\text { corn, in-growing toe } \\
\text { nails) }\end{array}$ & \\
\hline $\begin{array}{l}\text { Cutaneous viral } \\
\text { infections which might } \\
\text { have exponential } \\
\text { growths( preferably by } \\
\text { cryotherapy) }\end{array}$ & \\
\hline
\end{tabular}

All other procedures should be delayed till a downward trajectory of documented cases over a 14-day period is observed based on local scenario.

iii. All participating health care workers should use PPEs. The use of PPEs as per risk of exposure should be same for all surgical procedures regardless of COVID- 19 status (known, suspected, not-suspected). The removal and disposal of PPE should be

\section{References}

1. Phelan AL, Katz R, Gostin LO. The Novel Coronavirus Originating in Wuhan, China: Challenges for Global Health Governance. JAMA 2020 Feb;323(8). https://doi.org/10.1001/ jama.2020.1097

2. World Health Organization. Coronavirus disease 2019 (COVID-19) Situation Report - 51 2020. Available from: https://www. who.int/docs/default-source/coronaviruse/ situation-reports/20200311-sitrep-51-covid-19. pdf?sfvrsn=1ba62e57_10. [Accessed: June 19 2020].

3. Shrestha R, Shrestha S, Khanal P, KC B. Nepal's first case of COVID-19 and public health response. J Travel Med 2020 May;27(3):taaa024. https://doi. org/10.1093/jtm/taaa024 proper. PPE inside operation theatre includes respirator (N95 or above), gown, gloves, eye protection and cap.

iv. Use disposable instruments as far as possible.

v. Use absorbable sutures as far as possible in order to reduce number of visits.

vi. Electrocautery and laser ablation generate aerosols; hence, droplet precautions need to be taken. Use the machines under lower settings.

C. Keep track of department of health services, Ministry of health for updates on transmission of COVID-19 cases. If cases begin to increase, have a strategy in place to determine whether your practice will need to again temporarily reduce the service.

D. Have a plan in place for dermatology patients who appear with COVID-19 symptoms and require testing. Consider finding testing locations where you can recommend patients can go for testing or refer the patient to COVID designated hospitals.

\section{Conclusions}

In summary, this article presented the summary arising from recommendations involving 19 national experts. We have made recommendations for opening of Dermatological services - opening of outpatient department, performing dermatosurgical and cosmetic procedures as well as strategies on triage of patients and use of masks during crisis of COVID-19.

4. Singh R, Baral KP, Mahato S. An urgent call for measures to fight against increasing suicides during COVID-19 pandemic in Nepal. Asian J Psychiatr 2020 Jun;54:102259. https://doi. org/10.1016/j.ajp.2020.102259

5. Li H, Liu SM, Yu XH, Tang SL, Tang CK. Coronavirus disease 2019 (COVID-19): current status and future perspectives. Int J Antimicrob Agents 2020 May;55(5):105951. https://doi.org/10.1016/j. ijantimicag.2020.105951

6. Morawska L, Cao J. Airborne transmission of SARS-CoV-2: The world should face the reality. Environ Int 2020 Jun;139:105730. https://doi. org/10.1016/j.envint.2020.105730

7. Jackson LA, Anderson EJ, Rouphael NG, Roberts PC, Makhene M, Coler RN, et al. An mRNA Vaccine against SARS-CoV-2 - Preliminary Report. N Engl 
J Med 2020 Jul. doi: https://doi.org/10.1056/ NEJMoa2022483

8. International League of Dermatological society. ILDS guidance. Available at: https://ilds.org/ covid-19/guidance-dermatosurgery-cosmeticprocedures/. [Accessed: June 23, 2020].

9. American Academy of Dermatology. Reopening your dermatology practice. Available at: https:// www.aad.org/member/practice/coronavirus/ reopening-your-dermatology-practice. [Accessed: June 23, 2020].

10. Cembrano KAG, Ng JN, Rongrungruang $Y$, Auewarakul P, Goldman MP, Manuskiatti W. COVID-19 in dermatology practice: getting back on track. Lasers Med Sci 2020 Jun:1-4. https:// doi.org/10.1007/s10103-020-03043-w

11. Jindal A, Noronha M, Mysore V. Dermatological procedures amidst COVID-19: When and how to resume. Dermatol Ther 2020 May 12:e13561. https://doi.org/10.1111/dth.13561
12. Mysore V, Savita AS, Venkataram A, Inamadar AC, Sanjeev A, Chandrashekar SB, Devaraj DK, et al. Recommendations for cutaneous and aesthetic surgeries during COVID-19 pandemic. J Cutan Aesthet Surg 2020;13:77-94. https://doi. org/10.4103/JCAS.JCAS_83_20

13. Lahiry AK, Grover C, Mubashir S, Ashique KT, Madura C, Goyal N, et al. Dermatosurgery Practice and Implications of COVID-19 Pandemic: Recommendations by IADVL SIG Dermatosurgery (IADVL Academy). Indian Dermatol Online J 2020 May;11(3):333-6. https://doi.org/10.4103/idoj. IDOJ_237_20

14. Fahmy HD, El-Amawy HS, El-Samongy MA, Fouda AA, Soliman HS, El-Kady A, et al. COVID-19 and Dermatology: A Comprehensive Guide for Dermatologists. J Eur Acad Dermatol Venereol 2020;34(7):1388-94. https://doi.org/10.1111/ JDV.16545 